\title{
Knowing as Being, Knowing is Being
}

Doing a Political Ethnography of an Italian Right-Wing Party

\section{Elisa Bellè}

\section{CpenEdition \\ Journals}

Electronic version

URL: http://journals.openedition.org/anthropodev/438

DOI: $10.4000 /$ anthropodev.438

ISSN: 2553-1719

\section{Publisher}

APAD - Association pour l'anthropologie du changement social et du développement

\section{Printed version}

Date of publication: 1 July 2016

Number of pages: $79-100$

ISBN: 797-10-93476-03-2

ISSN: 2276-2019

\section{Electronic reference}

Elisa Bellè, « Knowing as Being, Knowing is Being », Anthropologie \& développement [Online], 44 | 2016, Online since 01 January 2017, connection on 19 April 2019. URL : http://journals.openedition.org/ anthropodev/438; DOI : 10.4000/anthropodev.438

La revue Anthropologie \& développement est mise à disposition selon les termes de la Licence Creative Commons Attribution 4.0 International. 


\title{
Knowing as Being, Knowing is Being
}

\section{Doing a Political Ethnography of an Italian Right-Wing Party}

\author{
Elisa Bellè
}

Que se passe-t-il lors d'une recherche ethnographique lorsqu'on "n'aime pas "ses indigènes"» (Avanza, 2008)? Cette question, simple mais fondamentale, est à la base de l'expérience ethnographique examinée ici: une étude des processus de participation et de militantisme au sein de deux sections de la Lega Nord, formation politique italienne de matrice populiste et xénophobe. Le travail de recherche a mis en évidence de nombreuses contradictions: principalement générées par mon opposition personnelle à la politique étudiée et plus particulièrement par mon activisme dans des groupes féministes et le bloc politique de gauche. Cette implication politique et personnelle a constitué une sorte de "secret inavouable " auprès des militants/tes de Lega Nord tout au long de mon enquête. Dans cet article j'essaye d'aborder les problématiques liées à cette identité cachée en l'analysant sur trois niveaux. (1) Relationnel : les implications considérables liées à mon choix de cacher une partie aussi importante de ma personnalité vis-à-vis de la conduite de ma recherche et de la qualité des relations établies sur le terrain. (2) Epistémologique: I'histoire de mon identité cachée peut être envisagée comme une trajectoire de recherche alternative qui $m^{\prime}$ a permis de récolter d'autres données et qui conduit à des résultats différents. (3) Politique : faire de la recherche sur des sujets politiquement "détestables " oblige le/la chercheur/euse à choisir entre des "loyautés incompatibles", celles envers I'humanité des militants/tes et celle envers lui/elle-même et ses convictions (Bizeul, 2007). 
What happens in ethnography, "when you don't like 'your natives'" (Avanza, 2008)? This question represents the starting point of the present contribution and also the basis of my ethnographical experience: research on participation processes in an Italian right-wing, populist political party, the Northern League. The research was conducted in two local party sections, respectively located in a small town and a large metropolitan area of two North-Italian regions (Veneto and Lombardia). The ethnographic work mobilized several and interrelated contradictions: firstly, because of my personal opposition to the political culture studied; secondly, in consideration of my experience as a feminist and left-wing activist, which remained a sort of "unsayable secret" with the militants during the entire fieldwork. In my contribution, I try to deal with these contradictions at three different levels of analysis. (1) Relational: the relevant implications of hiding a fundamental part of my personality deeply involved in the research process. (2) Epistemological: the story of my hidden identity can be viewed as the story of another research trajectory with different data and results. (3) Political: doing research on a politically "detestable" subject constantly forces to choose between "incompatible loyalties" (Bizeul, 2007). In my case, I had to choose between maintaining non-conflictual relations with the militants or expressing my opposition to their political and gender beliefs and behaviors, thereby revealing my political experience and views.

\section{Introduction}

What happens in ethnography, when the researcher is doing fieldwork on political groups characterized by ideals, values and languages that stand in opposition to the researcher's own political views and experience? How can the researcher deal with the ambivalent and problematic feelings that this political and personal distance may generate? This dilemma constitutes the basis of my ethnographic experience of doing fieldwork on militancy in an Italian right-wing, populist party, called Lega Nord (Northern League). A review of contemporary political ethnography has shown 
that almost $90 \%$ of the studies on political movements and/or groups concern progressive movements (ecologists, feminists, LGBT, civil rights movements, and so on) (Blee, 2007; Avanza, 2008). In contrast, ethnographic studies on politically "problematic" subjects, such as extreme right-wing, populist and racist groups, movements or parties are still quite rare, although they are growing in number ${ }^{1}$. Political ethnographies on problematic groups of this type pose several problems, in terms of both epistemology and methodology. The most salient of these problems are the following:

- Managing in an appropriate manner possible conflicts between the researcher's and the research subjects' values.

- Dealing with the challenging issue of the researcher's position in the field.

- Being aware of the strong impact of this position on the research process (collecting and interpreting data).

- Taking account of the crucial role played by reflexivity in situations of conflict.

In this contribution, I address these issues with reference to my own research experience, which mobilized several interrelated contradictions, not the least because of my personal story as a feminist and left-wing activist; an identity which remained a sort of "unsayable secret" during the course of the fieldwork. After outlining my research design and methodology, I analyze the question of my relationship with a politically problematic field in light of three levels of contradictions that emerged during the research process. At a relational (and deontological) level, I was concealing from the research subjects an important part of my

${ }^{1}$ For some of the major ethnographical studies carried out on political actors problematic because of their ideological practices and/or positions see, e.g., Fielding, 1982;

Boumaza, 2001; Bizeul, 2003; Black, 2004; Blee, 2007; Avanza, 2007; Di Nunzio and Toscano, 2011; Nikolski, 2011; Cammelli, 2015. 
personality (my political views and experiences). At the epistemological level, revealing my "hidden identity" as a politically engaged person would have led to another possible research trajectory. And last but not least, at a political level, I was constantly forced to choose between "incompatible loyalties" (Bizeul, 2007). I had either to hide my political view, in order to maintain nonconflictual relations with the militants, or to express it, thereby risking to compromise my fieldwork.

The present contribution is an attempt to reflect methodologically and epistemologically on the experience of a political ethnography that can also be viewed as a missed encounter between politically conflictual worlds (namely, that of the researcher and that of the research subjects). In the following sections, I try to deal with this (emotional, human, political, intellectual) complexity by analyzing how my positioning as subject and my values and political categories played an important role in the everyday practice of fieldwork, arguing that the difficulties generated by immersion in a field perceived as politically hostile may turn into an extremely powerful interpretative resource.

The research: ethnography of a populist party

The Northern League (Lega Nord) is a regional Italian political party foun-ded in the late 1980s from the federal aggregation of a wide and varied series of small regional leagues. The party has its most stable and deepest roots in a specific area of Italy. This is the geopolitical context of the so-called "white" political subculture (subcultura politica bianca): an econo-mic and sociopolitical model that characterizes large areas of North-East Italy and is based on the productive structure of small businesses and the overlapping of familial and socio-economic networks (Diamanti, 1993). In a sociopolitical perspective, it is a peculiar area based on the defense of private interest; a social integration largely managed by catholic associative networks; a hostile, mistrustful attitude towards political institutions and parties (a sort of "antigovernment localism"). This area also used to be characterized by the long electoral dominance 
of the Christian Democratic Party. Then with the gradual but inexorable decline of the hegemony of the Christian Democratic Party (from the late 1970s), the Northern League has acted as a political entrepreneur in this phase of crisis and change, giving voice to the area's new tensions, conflicts and contradictions. The party has brought about a major shift in the "classic" twentieth-century political citizenship paradigm, by constructing a political proposal that can be defined as the ideologization of the concept of "territory" (Diamanti, 1996; Biorcio, 1997). A new political paradigm no longer based on the left/right dichotomy and the class vote but on populist (Biorcio, 2012) and communitarian (Diamanti, 1993; Bellè, 2015) forms of post-ideological identification. Firstly, in a populist political culture, the sense of community and territorial belonging replaces class identification. Secondly, conflict is depoliticized and projected outside the community's boundaries onto various categories of alterity (southerners, immigrants, Roma, homo-sexuals), all equally constructed as threatening and deviant "strangers" (that become, literally, "non-communitarian"). Consequently, even rights are localized (Gargiulo, 2011) in that they are no longer granted by citizenship, but ascribed by membership of the community.

My main objective in the research project was to approach the Nor-thern League, not so much as a macro political actor on the institutional or media scene, but rather as a concrete and locally situated organization, lived and sustained by grassroots activists and local leaders. For this reason, I chose to undertake ethnographic work which would bring me as directly as possible into contact with the practices and everyday lives of the militants within their social worlds. To this end, I selected two different local branches, which have been given the fictitious names of Contrada and Metropolis. The two branches were chosen for their location at the opposite extremes of two analytical axes: a territorial axis and an organizational one. Contrada is a Northern League branch in a small town of Veneto (North-East Italy). It is in a central position from a territorial point of view, because Veneto is at the core of that white political subculture that was the birthplace of the 
Northern League, but peripheral with respect to the politicalorganizational axis. By contrast, Metropolis, located in a large city of Lombardy (North-West Italy), is peripheral from a territorial perspective. Large urban areas are in fact the places of least consensus (Passarelli and Tuorto, 2012a) for parties like the Northern

"valley-dwelling and provincial party" (Agnew et al., 2002). Metropolis, however, is central on the internal organizational axis because it is close to the managerial, organizational and political heart of the party.

Gaining access to the field was relatively simple and quick. Thanks to a colleague of my Department, I contacted a militant of the Contrada branch. He first spoke with the branch's secretary, presenting me as a young researcher interested in the party and in its organizational life. This first negotiation was successful, so I planned a meeting with militants and local leaders, illustrating my research interests. After this first meeting, I was allowed to participate in the branch's life. And after six months of participant observation in Contrada, I gained access to the Metropolis branch, thanks to the internal party network. A young militant of the Contrada branch presented me to the secretary, whom she knew personally. She played the role of guarantor, explaining the positive experience of my presence. The secretary of Metropolis consented to my access after a first meeting, and I started to participate regularly in the branch's activities.

In sum, I entered the field by knocking on the party's doors, declaring my identity as a sociologist and explaining my research interests. I opted for non-covert observation for several reasons: firstly, because of the ethical implications of covert ethnography, particularly in terms of building a relationship based on transparency and trust between the researcher and the social actors in the field. Secondly, in consideration of the extreme difficulty of covert observation, both in practical terms - pretending to be a militant was a rather unlikely eventuality - and emotional ones, carrying the weight of a constant fiction about my person and my presence. Al-though my identity and intentions as a researcher 
were declared, I was hiding important aspects of my personality, relevant also for the research process. Indeed, I did not mention to the informants my experience as a feminist and left-wing activist, which remained a sort of "secret", a hidden identity, during the entire fieldwork. From a formal point of view, I was "just" a young researcher coming from the university with her notebook but, from a political point of view, I could represent a sort of ideological nightmare for the militants. Hence I decided to omit the political side of the story; with the consequence that the research, although formally non-covert, partly retained features of covert ethnography. My data were collected through overt participant observation of ordinary party activities ${ }^{2}$ : mainly the weekly branch meetings, but also various kinds of political and convivial initiatives (public demonstrations and events, flyering, social dinners, and the like). At a more advanced stage of the fieldwork, I added ethnographic interviews with militants and leaders of both branches ${ }^{3}$.

\section{The fieldwork: story of a missed positioning}

Before describing my fieldwork experience, I should first clarify why I decided to study this particular political party. First of all, my main research interest concerned the relations between gender and militancy in political parties. Moreover, I wanted to investigate the relation between political cultures and gender cultures, my purpose being to highlight the possible connections and reciprocal influences between these two dimensions. Finally, my goal was to focus more specifically on the construction of masculinity: a theme as central to the analysis of political participation from a gender perspective as it is paradoxically little addressed by empirical research, which tends

\footnotetext{
${ }^{2}$ My participation was not continuous. I did not live in Contrada or in Metropolis. I stayed in each branch for approximately six months, but my presence was limited to the party activities (formal and informal).

${ }^{3}$ The research began in the branch of Contrada, where the observation was carried out between April and November 2011 (with a break during the summer) and then moved to Metropolis, between December 2011 and May 2012.
} 
to focus much more on the under-representation of women. Once I had identified the macro-theme of interest, I then had to select a specific political party. The choice fell on the Northern League for various reasons. First, it is a party that, amid a general crisis of grassroots political militancy, still has a certain vigor in terms of geographical pre-sence and active participation by its members (Cento Bull and Gilbert, 2001; Passarelli and Tuorto, 2012a). Second, the Northern League is a party which is markedly imbalanced in terms of the gender composition of its rank and file activists, who are predominantly male (Passarelli and Tuorto, 2012b). Third, the Northern League is a political party whose public discourse and symbolism convey clear and strong elements of virilism (Avanza, 2009; Bellè, 2014). Consider, for example, the fundamental role of its historical leader and founder, Umberto Bossi, who flaunts a deliberately rough masculinity (De Matteo, 2007; Belpoliti, 2012) (one of Bossi's best known phrases is "We of the League have hardons"). Moreover, many of the party's core ideological issues are couched in a bellicose rhetoric: so-vereignty and territorial control (another well-known League slogan, in fact, is "Masters in our own house"), the maintenance of order and decorum, and racist and anti-homosexual positions.

The research topic put me in a complex and contradictory situation: the organization best suited to my research interests proved to be very distant from my beliefs, values, and life choices. Moreover, my scientific interest in the party was also nurtured by a general interest in politics, conducted in a very distant field, namely that of leftist and feminist social movements. This problematic aspect was exacerbated by methodological considerations: ethnography works through direct and generally prolonged presence in the field, and it is based on the ethnographer's presence and involvement in the social world under analysis. The relational proximity requested by the ethnographical method, in cases of politically problematic research subjects, raises a crucial question concerning the "appropriate ethnogra-phic distance" (Bensa, 1995) and the management of contradictory emotions and feelings. "Being there" forced me to deal with the ambivalence 
created by the conflict between a radical political distance and the human empathy generated by my prolonged relation with the research subjects.

As already anticipated, this issue raises several questions in relation to the more specific field of political ethnography. The complexity that the immersive study of politically "problematic" groups can generate partially explains the scarce number of ethnographies of this type (with the exception, among others, of: Fielding, 1982; Boumaza, 2001; Bizeul, 2003; Black, 2004; Blee, 2007; Avanza, 2007; Di Nunzio and Toscano, 2011; Cammelli, 2015) and the prevalence of political ethnographies on progressive movements (Blee, 2007). Reflexivity and position in the field become particularly problematic when the researcher finds that he/she not only cannot "stand by" his/her object of study, but even harbors critical opinions and feelings (Bizeul, 2003; Black, 2004; Avanza, 2008; Blee, 2007; Nikolski, 2011). In these cases, the immersion in the fieldwork may constitute a source of several conflicts (with the research subjects and/or in terms of a struggle internal to the researcher), often accompanied by an intense and controversial emotional state. This peculiar situation requires especially competent work in terms of the ethnographer's awareness. He/she should pay great attention to his/her position in the field: what kind of actions, reactions and relations is he/she establishing? How is this position influencing the research process?

In order to deal with all these relevant epistemological and methodological problems, it can be particularly helpful to connect the debate of "problematic" political ethnographies to the debate on feminist epistemology ${ }^{4}$. Feminist epistemology, indeed, provides important considerations about the relational and embodied character of knowledge, which in turn constitute an important

\footnotetext{
${ }^{4}$ This too is a vast topic, addressed by a huge number of studies, also because of its inter- and trans-disciplinary character. Given the difficulty of providing an exhaustive list of references, I mention only some of the fundamental contributions to the debate, particularly relevant to my reflection here: Harding, 1986, 1991; Haraway, 1988, 2004; Barad, 2007.
} 
methodological tool in order to deal with the complexity and ambivalence of studying a politically "hideous" phenomenon. In particular, the concept of positioning as source of situated knowledge (Haraway, 1988, 2004) and "strong objectivity" (Harding, 1991) can be particularly relevant in relation to the ethnographical study of poli-tically controversial phenomena. Positioning can be defined as a cognitive practice that makes self-reflexivity the foundation of research itself, finally freed from the presumption of neutrality and objectivity assumed by the modern thought of rationalist and positivist stamp. The knowledge that we (as researchers, but also as human beings) produce, indeed, reflects our locationality (historical, national, generational) and positionality (gender, class, sexuality and so on). Moreover, our positionality is not ascribed, fixed; on the contrary, it is relational:

"A constantly moving context that constitutes our reality and the place from which values are interpreted and constructed" (Geiger, 1990: 171).

Feminist epistemology calls into question research practices based on detachment and the subject/object hierarchy of research. Every form of knowledge, therefore, is rooted in subjectivity and related to embodied experience. The subject is no longer an awkward presence that undermines the rationalist "objectivity" of knowledge and which should therefore be concealed; rather, it is the embodied starting point which guarantees the validity of the research process.

An illustrative example of dealing with my position in the field being aware of its relevance for the research process - occurred during my first evening of participant observation at the Contrada branch:

(Weekly meeting) "A militant says 'Fifty Tunisians have arrived in [***] (a nearby town)'. The Secretary, at the other end of the table, replies 'We could give a piece to the dogs... but we don't have a meat grinder', followed by laughter and submissive smiles, which I think were muted partly because of the harshness of the joke, partly because of my presence, not yet clear from a political point of view. The Secretary 
looks at me and observes my reaction. I keep my head down and, after a very long moment of hesitation, I raise half a smile. While I choose to smile I felt awful. Later on, going back home, I wonder whether it was a sort of test to understand my poli-tical views. In any case, I read it in this light and played along with it for fear of spoiling the 'vibe' by being aloof. An ethical, but also emotional issue" (Ethnographic diary, 4 April 2011).

In cases like that exemplified by the excerpt, the ethnographer is faced with "incompatible loyalties" (Bizeul, 2007): between himself/herself, his/her beliefs, his/her own world of origin and the research field, with its inhabitants. Of course, before I started my fieldwork, I was (theoretically) aware of the potential problems related to my research subject. I tried to circumvent these problems by reading about the Northern League and about other, similar research experiences. I quite carefully planned my fieldwork, reflecting on possible answers to difficult questions and appropriate reactions in different situations. However, it is difficult to establish a precise course of action in advance or to predict specific conflictual situations and reactions, both on my part and on the part of my informants.

As already pointed out, a particularly problematic aspect related to reflexivity and positioning has to do with my "hidden" political identity of left-wing and feminist activist. This identity, if disclosed, could have triggered the aversion of my interlocutors (for these types of ethnographical experiences, see Fortier, 1996; Bizeul, 2007).

The identity and political dilemmas deriving from omission are exemplified by the episode reported below:

(Social dinner, Metropolis's branch) "I am attending a social dinner organized by the branch. I am sitting next to the Mayor of a nearby town. I introduce myself and explain why I am here, and almost immediately he asks, out of the blue, 'Who do you vote for?' Puzzled, I look at him and mutter some embarrassed 'Errs...', giving rise to an ironic smile and a sentence that sounds like 'You can answer, it's not a 
problem.' I reply that, for me, politics is not that significant from the vote point of view, that I'm interested in it for my studies and that I'm not particularly fond of any party. Then I tell him, falsely, that I voted for a moderate, autonomist party in the region where I come from. I explain that that party is not a particularly significant party in my region because it is the heir to the Christian Democratic Party and everybody votes for them. He seems satisfied by my ans-wer and the conversation subject changes, as I hoped" (Ethnogra-phic diary, 29 May 2012).

Not without irony, fate turned against me just when I no longer expected it: after spending months in fear that it might happen, on the last evening I was finally asked about my political position. My reply was an outright lie. I lied twice, both with respect to my voting choice, and with respect to my purely "scientific" interest in politics, which is instead also and deeply personal. Indeed, my interest in politics has marked my whole life because it is one of the main reasons that led me to make it a subject of my research. It was a double lie also with respect to relational intentions. Firstly, because it was intended to shift the interlocutor's attention from my political ideas to my identity as "neutral" researcher. Secondly, I lied choosing a party I never voted for, simply because, given its territorial nature, this party could be a point of affinity with the militants. In short, my reply was incorrect from a relational and deontological point of view, but which at the same time was indicative of my desire to produce results at any rate, even though it made me unhappy (because of the contradictions I had to live through).

The problematic aspects of the research related not only to my own political opinions and experiences but also to my identity and gender performances as a young female researcher (on a similar research experience, see Fortier, 1996; McQueeney, 2013). In fact, during my research I repea-tedly found that my gender identity, together with my (relatively) young age, reassured my interlocutors, assigning me a less threatening role. 
(A public party's event, Contrada) "Today I went to the inauguration of an important public work, in a town near Contrada, which was also attended by the President of the Region, a well-known personage admired by the militants. I went with the branch Secretary and a young female militant. The Secretary introduced himself as the De-puty Mayor, since he actually holds that office. Thanks to his institutional role it was possible for us to bypass security checks by using an entrance reserved for the authorities. At the entrance an officer asked the Secretary - a middle-aged man - who 'the two girls' with him were. He replied 'They are my assistants', showing a certain pride at turning up for an official celebration with two young wo-men. There followed evident manly looks and smirk of complicity between the two men. The young female militant smiled, while I felt terribly uncomfortable and pretended not to understand the allusion" (Ethnographic diary, 10 November 2011).

(Christmas dinner party, Metropolis) "Gigi (a middle-aged militant) comes to my table and says that 'We (the militants) have thought about it and decided to take you home by car', because public transport is not much used, especially at night. I thank Gigi, who goes away. After a while Giovanni, another militant, tells me exactly the same thing. He adds that on the bus that I have to take there are few Italians and numerous immigrants. He says that it could be dangerous, especially for a 'young woman' on her own" (Ethnographic diary, 23 December 2011).

One of the most frequent relational codes - very clearly exemplified by the first excerpt - was modelled on a kind of benevolent paternalism: "mature and expert" male militants showing their world to the young female researcher, activating forms of light organizational flirting (Pringle, 1989). It is important to notice that this attitude involved also the women of the party, often subjected to irony, erotic jokes and in general confined to an ancillary role. This aspect was particularly contradictory for me: on the one side, I felt a very empathetic solidarity towards women who, in my pers-pective, were openly discriminated against; on the 
other side, it was clear that those women actively took part in that gender order and system of values.

Moreover, in some cases, the paternalistic attitude mingled with - and to some extent was used to reinforce - other reactionary ideological attitudes. The second excerpt from my ethnographic diary exemplifies the use of the female body (in this case mine) as a symbolic resource to reinforce the idea of a hostile alterity (immigrants as a threat to "our women").

\section{The implications of (non-)positioning}

Although focused on different themes, the above-mentioned episodes have an important aspect in common: my silence, my lack of reactions, a sort of missed positioning. Faced with strong political and ethical solicitations, I chose to mask my feelings and opinions. This decision played an important role in the research process, in relation to three main aspects, examined in the following section: relational, epistemological and political.

\section{Relational implications: identity and emotions}

As already mentioned, the decision to hide myself behind the identity of a "neutral" researcher turned out to be oppressive and conflictual. Hence, my choice not to reveal anything about my experiences as a political activist proved to be a decision somewhat difficult to manage throughout the fieldwork. I spent most of the time in fear of being unmasked: a simple online search would have sufficed to discover my enormous distance from the ideas of the party. This concealment, besides being difficult to manage in terms of constant control over myself, also caused a sense of relational distress. My fieldwork experience was ambivalent and nuanced: I shared several moments with the militants, establishing a special empathy with some of them. Therefore, I often felt dishonest and disrespectful towards people that, although distant from my opinions and values, were revealing themselves to me and inviting me into their organizational and political world. In dealing with this, 
I tried to go beyond superficial and useless guilt by reflecting more thoroughly on my situation. My choice of performing a "purely scientific" identity had been heavily influenced by the fear that the research might be halted by the militants if they became aware of my political opinions and activities. However, there were also more personal and emotional issues at play. I chose to hide myself behind the scientific "neutrality" of a researcher also to achieve a certain serenity. Doing ethnography in an "adverse" field, concealing my political views and experience, generated in me a sense of exposure and potential vulnera-bility. This perception was reinforced by the aggressive political rhetoric often used by the militants towards the ideological "enemies" of the party. In this emotional state, I was very conscious of my limitations: I knew that I certainly would not have been able to manage an open conflict with the militants.

Studying political subjects extremely distant from the researcher's

values and personality can generate feelings of fear (Blee, 1998), confusion, and disorientation of identity and emotions (Bizeul, 2007; Nikolski, 2011). Despite their importance, these emotional aspects have been surrounded by an academic silence that also confirms the tendency to cons-truct scientific discourses marked by the rationality/emotivity dualism intended to objectify and disembody knowledge (Harding, 1986, 1991; Haraway, 1988). My main relational difficulty lay in the conflict between openness and humane empathy towards the social world under study and its political culture, which for me was unappealing.

Epistemological implications: when the unspoken and the unknown turn into research data

The conflictual condition arising from the problem of taking position in the field furnishes further opportunities for reflection on epistemological aspects. In this regard, considerations on the issue of the ethnographer's access to organizational fields are particularly significant. Negotiating access to the field within an organization can in fact be regarded not so much as a circumscribed early phase but as a continuous process: a sort of trajectory that the researcher 
negotiates during the entire course of his/her fieldwork (Bruni, 2006). It is a process that ramifies, deviates and changes, in which the researcher makes choices dictated by circumstances and opportunities that in turn can determine a certain development of the research instead of others.

In my case, for example, I missed some opportunities to collect data that, when they arose, I was unwilling to take. For example, at the end of the branch meetings in Metropolis, a large group of militants would usually go to a nearby pub to close the meeting with a few drinks together. Whilst it was possible for me to join them, I chose to do so only twice. I decided to decline in order to avoid dealing with a burdensome situation, especially at the end of already stressful participant observation at the branch. This decision meant that I forfeited opportunities to take part in backstage moments of that section's life which could have been important. Plagued by a sense of ethnographic guilt, I wondered, in the first instance and very banally: why at Contrada do I go willingly to the bar with the militants after the meeting and at Metropolis I am so reluctant to do so? What causes this resistance to doing something that I have already shown that I can handle? My answer was unequivocal: it was a matter of "atmosphere": in one case I felt comfortable and relaxed; in the other, potentially hostile and cold.

On the basis of this first, very basic consideration, I began to "follow my feelings" and reread the data and the ethnographic experience more carefully, focusing on relations between the militants (and me). I realized that in the case of Metropolis there were much more overtly hierarchical relations, marked by a kind of militaristic virilism and a strong form of identification with the party very much based on control with respect to the outside world. At Contrada relations were instead rather close and confidential. The model was not the military one, but rather the extended rural family (not necessarily less vertical or patriarchal, but decidedly more welcoming in relational terms). I then connected these considerations to the different territorial contexts of the two sections. At the Metropolis section, in a socially diverse and fragmented city, the identitarian "glue" which held very different 
and disconnected militants together consisted of the party itself, understood as a primary ideological resource able to draw an identificatory boundary. At the Contrada section, in a provincial town with numerous small-medium local firms, social ties constituted the most important resource for identification, which the party tended to reproduce within itself, maintaining a light and, so to speak, "camouflaged" ideologization towards the outside.

So, my initial guilt at having missed opportunities for participant observation changed into a stimulus to reflect on and re-interpret the data, which then generated more significant conclusions in analytical terms. Therefore, reflecting on what was unspoken (my non-positioning) or unknown (data not collected) in the research experience may be a source of important epistemological reflection on what can or cannot aspire to the status of research data. Only at the end of the fieldwork did I realize that silences and ambiguities spoke much more eloquently and clearly than my initial sense of failure as a "fearful ethnographer" had me believe.

\section{Political implications}

Finally, doing research on a political "problematic" organization enabled in-depth analysis of the several political implications of ethnography. It highlighted how the identity positioning of the ethnographer may have profound effects on the construction of data and on the entire research process, as well as on the inevitably political nature of the observational relationship.

More specifically, two main political issues arise from my research experience. The first has to do with a certain representation of science, knowledge, and their statuses, which I contributed to reproduce during the fieldwork phase. It was a sort of "identity cover", that of a neutral researcher who observes and studies without being directly involved in the process because he/she looks at the world with the detached (or superior) eye of a scientist. Through implementation of this code I made myself (almost) untouchable, thus gaining a position of contingent serenity. But, at the same time, I reinforced a certain cultural stereotype, 
which was also a sort of intellectual "inferiority complex" found in many of the militants. The Northern League is in fact a party that has made ignorance and rudeness an identificatory and symbolic populist resource (De Matteo, 2007), although associated with a certain degree of social stigma. The party seems to have ambivalent feeling toward intellectuals, who are at the same time the object of hostility and unconfessed admiration.

By choosing to play the role of the "neutral" researcher, I turned this unconfessed, ambivalent admiration, this elitist view of science in a sort of relational weapon, in order to remain untouched by possible conflicts. By so doing, however, I confirmed and strengthened - in the small portion of the social world observed - a representation of culture and "intellectuals" that is part of the party's populist political discourse: the populist cleavage between "us", the simple and rude people that do not need very complicated discourses in order to understand things as they really are, and "them", the leftist intellectuals that oppress the people with elaborate lies. Moreover, an even more important element is that I ended up reinforcing a representation and a politics of knowledge that in other contexts I fiercely criticize and strongly contest.

Secondly, and in a more general sense, I experienced the political aspect of the ethnograph(y)er in reflexive terms. I became entangled in a web of political codes that, while not sharing them, I partially reproduced: the already-mentioned representation of science; the gender relations of a sexist nature; the racist and populist utterances which I did not contest. From this point of view, the peculiar situation of the ethnographer - as the tool and subject of the observational process - afforded me the fundamental epistemological experience of becoming part of the political culture that I intended to study.

Concluding remarks: knowing as being, knowing is being

In this final section, it is important to recall the more relevant points rela-ted to this particularly contradictory ethnographical 
experience. Studying a (for me) politically problematic subject made it possible to analyze in depth the conflictual interplay between the empathy of the human relations established in the fieldwork and the inevitable "hardening" process that arises from studying politically "hostile" subjects. When studying a culture that the ethnographer does not sympathize with - and vice versa - it is necessary to deal with the general, profound ambivalence of the ethnographic method that challenges emotions, subjectivities, and vulnerabilities by prescribing a relational exchange, even (and especially?) when it is a source of conflict.

In relational terms, the research experience on politically "hideous" subjects is a sort of "ethnographical reversal" in the relationship between ethnographer and field. In the case of my research experience (and in other, similar ones), indeed, the ethnographer is part of a minority (extreme-left activism and feminism) within a social world that embodies a more dominant culture. In this sense, therefore, the interpretative categories and "marginal" characteristics of the researcher highlight the social and cultural centrality of the world under study, within an inverse relationship between centre and margin.

This inversion of perspectives has two main consequences. The first, as already mentioned, is the relational difficulty of positioning. Regardless of the countless relational choices that I could have made, what matters here is their difficulty, the challenge of emotions (Blee, 1998), such as identity disorientation (Bizeul, 2007), fear and a sense of vulnerability, that would not have been stressed as much in a "loved" research field.

The second implication is epistemological: the positioning difficulties led to important omissions (something that remained "unspoken") about my opinions and identity and to the forgoing of opportunities for observation due to emotional difficulties caused by the context (something that remained "unknown"). These dimensions of "unspoken" and "unknown" speak eloquently of both my relationship with my interlocutors and the characteristics of the 
social world that I observed (in relation to mine, of course). Therefore, these "missing data" constitute, like the collected data, valuable insights on the adequate reflexive awareness needed both during the research and in the textual restitution of the ethnographical work.

Moreover, studying politically "problematic" subjects forces the researcher also (and probably above all) to deal with his/her own political categories, which clearly become part of the production of knowledge. This dynamic, which applies to all forms of knowledge and is never neutral (Harding, 1986, 1991; Haraway, 2004; Barad, 2007), emerges with all its cogency in the analysis of political subjects, representing, despite the difficulties and contradictions of the process, one of its most fascinating heuristic potentials. As illustrated by some "ethnographic incidents" that occurred during my fieldwork, the problematic/hostile character of the political phenomenon studied forced me to be almost always constantly aware of the dynamics of reciprocal positioning, therefore conducting an extremely careful (self)reflection.

The awkwardness of my position (the silences, omissions, compromises of values) paradoxically proved to be a sort of multiplier of knowledge: whenever I could not "be myself", my understanding, both of myself and the culture studied, became more acute and profound precisely because of the distance and the difficulties. Indeed, what I initially interpreted as obstacles and weaknesses of my research turned into an analytical resource that allowed me to reflect more accurately on my methodological choices and my epistemological perspective.

In conclusion, I would add a broader, albeit provisional and exploratory, consideration raised by the ethnographic study of "detestable" political phenomena. Added to, and interwoven with, the crucial importance of reflexive awareness throughout the whole research process (see, among others, Bourdieu and Wacquant, 1992) is the issue elaborated in feminist theories and epistemologies about positioning and standpoint (Harding, 1986, 1991; Haraway, 2004). On examining the data collected, I realized 
that, in order to interpret them better, I had to resort to my political categories, making my distance from the political culture under study an analytical resource rather than an obstacle. My being a woman with a history of feminist and left-wing political activism could not remain simply an omission, a sort of missed "coming out" with my interlocutors. It was one of the drivers that most profoundly induced me to "be there" and study such a distant culture. The questions that motivated my inquiry were roo-ted in my irreducible distance, which prompted me to enquire about, to want to "understand", to look closely at something so irremediably distant. My cultural and political distance from the research subject was not an accident, but the real crux of the research. The only good knowledge I could draw from the whole story, I would have drawn not by hiding but rather by valuing my (political and interpretative, if ever there was a difference) categories, thus beginning from myself and my own experience. Hence, ultimately, the study of political phenomena disliked by the ethno-grapher makes the onto-epistemological character of the production of knowledge (Barad, 2007) particularly evident, underlining the insepara-bility between forms of being and forms of knowledge.

\section{References}

AGNEW J., SHIN M. and BETTONI G., 2002, "City versus Metropolis: The Northern League in the Milan Metropolitan Area", International Journal of Urban and Regional Research, 26(2): 266-283.

AVANZA M., 2007, "Les "purs et durs de Padanie". Ethnographie du militantisme nationaliste à la Ligue du Nord, Italie (1999-2002) ", thèse de doctorat sous la direction d'Alban Bensa, EHESS, Paris.

AVANZA M., 2008, "Comment faire de l'ethnographie quand on n'aime pas "ses indigènes"? Une enquête au sein d'un mouvement xénophobe ", in FASSIN D. and BENSA A. (eds.), Les politiques de l'enquête, Paris, La Découverte: 41-58.

AVANZA M., 2009, "Les femmes padanes militantes dans la Ligue du Nord, un parti qui "l'a dure" ", in FILLIEULE O. and ROUX P. (eds.), Le 
sexe du militantisme, Paris, Presses de Science Po: 143-165.

BARAD K. 2007, Meeting the Universe Halfway. Quantum Physics and the entanglement of Matter and Meaning, Durham, London, Duke University Press.

BELLÈ E., 2014, “Costruire la comunità, tra patriarchi e camerati. Nessi tra cultura politica e ordine di genere in due sezioni locali della Lega Nord", Studi Culturali, 11(1): 29-54.

BELLÈ E., 2015, “Inside the 'black box' of the Northern League's populism: from territory to community", Etnografia e Ricerca Qualitativa, 1: 89-109.

BELPOLITI M., 2012, La canottiera di Bossi, Milano, Guanda.

BENSA A., 1995, «De la relation ethnographique. À la recherche de la juste distance. Une lecture du livre de Philippe Descola, Les Lances du crépuscule, Relations Jivaros, Haute-Amazonie, Paris, Plon, 1993 ", Enquête, 1: 131-140.

BIORCIO R. 1997, La Padania promessa, Milano, II Saggiatore.

BIORCIO R., 2012, "I populismi in Italia", La Rivista delle Politiche Sociali, 1: 35-57.

BIZEUL D., 2003, Avec ceux du FN. Un sociologue au Front national, Paris, La Découverte.

BIZEUL D., 2007, " Des loyautés incompatibles », SociologieS, dossier " La recherche en actes, Dilemmes éthiques et enjeux scientifiques dans l'enquête de terrain ", [en ligne], last access 17 May 2016, http://sociologies.revues.org/226

BLACK L., 2004, "Politics, Research and Understanding”, in SEALE C., GOBO G., GUBRIUM J. and SILVERMAN D. (eds.), Qualitative Research Practice, London, Sage: 249-263.

BLEE K.M., 1998, "White-Knuckle Research: Emotional Dynamics in Fieldwork with Racist Activists", Qualitative Sociology, 21(4): 381399.

BLEE K.M., 2007, "Ethnography of the Far Right", Journal of Contemporary Ethnography, 2: 119-128.

BOUMAZA M., 2001, "L'expérience d'une jeune chercheuse en "milieu extrême". Une enquête au Front national ", Regards 
sociologiques, 22: 105-121.

BOURDIEU P. and WACQUANT L.J.D., 1992, An Invitation to Reflexive Sociology, Chicago: University of Chicago Press.

BRUNI A., 2006, "Access as Trajectory: Entering the Field in Organizational Ethnography", M@n@gement, 9(3): 129-144.

CAMMELLI M.G., 2015, Fascisti del terzo millennio. Per un'antropologia di CasaPound, Verona, Ombre Corte.

CENTO BULL A. and GILBERT M., 2001, The Lega Nord and the Northern Question in Italian Politics, Basingstoke, Palgrave.

DE MATTEO L., 2007, L'idiotie en politique. Subversion et néo-populisme en Italie, Paris, CNRS Editions.

DI NUNZIO D.A and TOSCANO E., 2011, Dentro e fuori Casapound. Capire il fascismo del Terzo Millennio, Roma, Armando.

DIAMANTI I., 1993, La Lega. Geografia, storia e sociologia di un nuovo soggetto politico, Roma, Donzelli.

DIAMANTI I., 1996, Il male del Nord. Lega, localismo, secessione, Roma, Donzelli.

FIELDING N.G., 1982, "Observational Research on the National Front", in BULMER M. (ed.), Social Research Ethics: An Examination of the Merits of Cover Participant Observation, London, Macmillan: 80104.

FORTIER A-M., 1996, "The Use of Personal Experiences as Sources of Knowledge", Critique of Anthropology, 16: 303-323.

GARGIULO E., 2011, "Localizzazione dei diritti o localismo dell'appartenenza? Abbozzo di una teoria della residenza", Società Mutamento Politica, 2(3): 241-261.

GEIGER S., 1990, "What's So Feminist about Women's Oral History? ", Journal of Women's History, 2(1): 169-170.

HARAWAY D.J., 1988, "Situated Knowledges: The Science Question in Feminism and the Privilege of Partial Perspective", Feminist Studies, 14(3): 575-599.

HARAWAY D.J., 2004, "Situated knowledges", in HARDING S., (ed. ), The feminist standpoint theory reader, London, Routledge: 81-101. 
HARDING S., 1986, The Science Question in Feminism, Ithaca, Cornell University Press.

HARDING S., 1991, Whose Science? What Knowledge?, Ithaca, Cornell University Press.

McQUEENEY K., 2013, “Doing Ethnography in a Sexist World: A Response to 'The Feminist Ethnographer's Dilemma'", Journal of Contemporary Ethnography, 20(10): 1-9.

NIKOLSKI V., 2011, " La valeur heuristique de l'empathie dans l'étude des engagements "répugnants" ", Genèses, 3(84): 113-126.

PASSARELLI G. and TUORTO, D., 2012a, Lega e Padania. Storie e luoghi delle camicie verdi, Bologna, II Mulino.

PASSARELLI G. and TUORTO D., 2012b, "Attivisti di partito nella Lega Nord: un caso anomalo?", Polis, 26(2): 255-284.

PRINGLE R., 1989, Secretaries Talk: Sexuality, Power and Work, London, Verso.

\section{Aivivivivis}

Elisa Bellè is Sociologist,

Department of Sociology and Social Research,

University of Trento (Italy)

E-mail: elisa.belle@unitn.it 